\title{
EFFECT OF WEIGHT IN MOTION DETECTION SYSTEM IN HUNGARY
}

\author{
Beatrix Ronay-Tobel ${ }^{1}$ \\ ${ }^{1}$ Department of Road Transport Control, Transport Authority of the Ministry for Innovation and \\ Technology, Hungary
}

Received 24 August 2019; accepted 22 December 2019

\begin{abstract}
In 2018, the National Dynamic Axle Weight Measurement System was introduced in Hungary. More than 100 control points were deployed countrywide. On this points the weight of road vehicles could be measured without stopping them, without harming the traffic. This paper aims to present the changes in road usage as a result of introducing the dynamic axle weight measurement system if any. The research hypothesis of this paper that the dynamic axle weight measurement system with the proper combination of highway code would not cause significant change on route choice and road usage patterns. Detailed statistical analysis of preliminary results was conducted separately for domestic and for foreign vehicles. Analysis of time series was done. Based on the results author could conclude that the introduction of the dynamic axle weight measurement system has not caused significant change, but also increased the effectiveness of control. Also, a preliminary economic investigation was elaborated.
\end{abstract}

Keywords: automatic weight enforcement, road usage, by-pass.

\section{Introduction}

It is following the successful example of the Hungarian road toll system and the intelligent road checkpoint system, a new dynamic weight control network was deployed in Hungary. This will also utilise the 'principle of objective liability. This means that in case of a vehicle- or axleweight limit violation, the administrative procedure is immediately initiated against the transport operator. Legally binding administrative decisions are generated like in case of speeding, or unauthorised usage of toll-roads. This means the margin of error is minimal when it comes to vehicle identification and the evaluation of WeightIn-Motion measurement data. In order to reach the social acceptance of such a system, all parties had to work in close cooperation (Šimecki et al., 2013; Oláh, 2016). The system detects over 40 million events monthly. Such a vast amount of big-data shall be collected and processed within the network in a way that effectively supports traffic control and road maintenance, meanwhile respects applicable information privacy and data protection acts (Oláh et al., 2018; Nesic et al., 2015). Preliminary technical details were already investigated and analysed (RonayTobel et al., 2019).

\section{Methodology}

For many years, operating overloaded cargo vehicles has been a 'low-risk high-yield' practice in Hungary, since carriers could achieve remarkable market. Static weight

\footnotetext{
${ }^{1}$ Corresponding author: beatrix.ronay-tobel@itm.gov.hu
} 
bridges present a much better inspection coverage, but they cause significant time loss. The dynamic weight-in-motion project in Hungary has achieved a significant increase on coverage and enforcement efficiency, featuring 107 stations monitoring 274 lanes with approximately 1500 quartz sensors. The development was financed (for over 90 Million EUR) by domestic budget and managed by the public-sector consortium of National Transport Authority of Hungary and the National Toll Payment Services Plc (Ronay-Tobel et al., 2019). Decision-makers have been guided by the well-known goals of the proposed solution:

- improvement of road safety (as overloaded vehicles pose an increased risk and severity of accidents) (Török, 2015);

- preserving the general condition of the roads (as overloaded axles significantly deteriorate the public roads network; its annual maintenance cost is larger than the total investment of project TSM) (Sipos, 2014);
- create a fair, competitive environment (as law-abiding businesses had to face a market distorted by carriers violating regulations for higher profit) (Oláh et al., 2017).

The existing infrastructure of the toll enforcement system provided a cost-efficient method of implementation, utilising its power-, communication-, and processing capabilities. The system is capable of detecting and measuring all types of vehicles, including cars, minivans, trailers, motorcycles. These drivers still have to comply with applicable weight regulations and may be subject to regular inspection by authorities.

Sensor arrays are installed in two basic configurations:

- Two sensor rows - used for preselection, calibrated for weighing;

- Three sensor rows - used for direct enforcement, certified by a notified body.

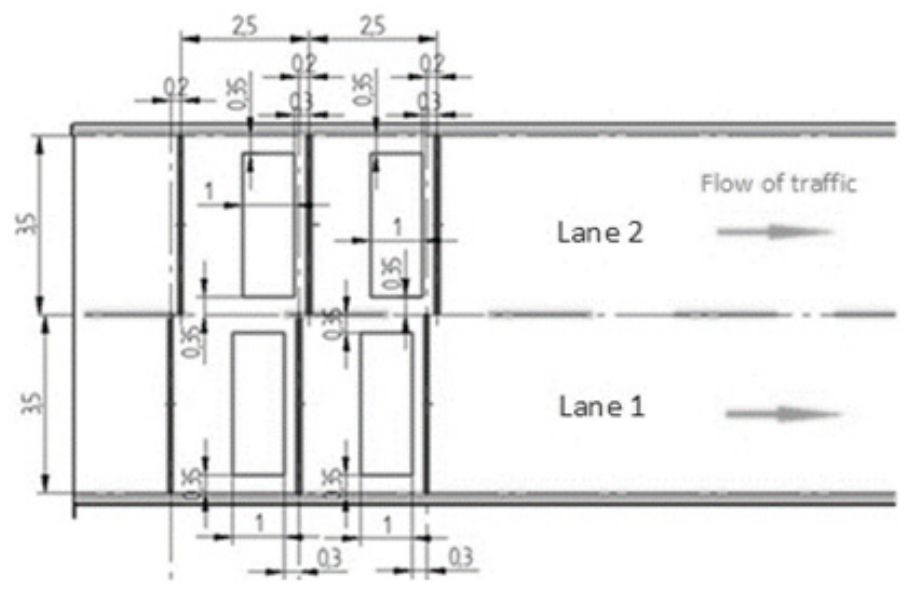

Fig. 1.

Typical Single-Line Layout Featuring 12 Quartz Sensors and Four Loops

Source: (Ronay-Tobel et al., 2019) 
Quartz sensors are installed in the full width of the road (including emergency lanes) in a single line (Fig. 1) or offset, depending on available lane width. The system is prepared to measure vehicles passing in-between two parallel lanes. Detection units have located the roadside. In order to meet 'Class I Excellent' quality parameters stated in COST 323 specification, providing appropriate geometric and mechanical conditions for high accuracy measurement (Jacob et al., 2002). Statistical analysis and assessment of measurement error of gross vehicle weight are characterised by 2.0..2.5\% interquartile range (IQR). Sites are featuring only two sensor rows and lower road quality classification, usually having $+0,5 \%$ higher IQR as seen in the boxplot below (Fig. 2). The boxplot covers a specific subset of reference vehicles that were present at the verification of both certified and non-certified (preselection) stations, therefore unloaded vehicles are excluded. The presented dataset should be considered as a base of comparison of site-layouts rather than the representative benchmark of quartz technology.

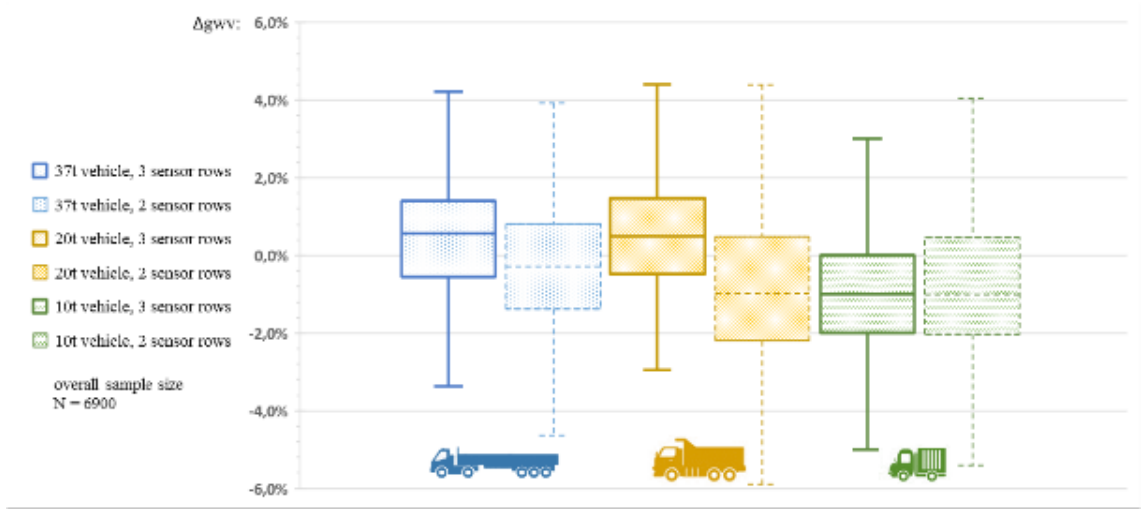

Fig. 2.

Distribution of Relative Error for the Gross Weight of Loaded Reference Vehicles

Source: (Ronay-Tobel et al., 2019)

\section{Results of Live Operation}

Although the system started to work on Sept 2017, automatically generated administrative fines for weight limit violations began to be sent out in July 2018. A considerable amount of data has been collected. An exact definition of "Big Data" is challenging to nail down because projects, vendors, practitioners, and business professionals use it quite differently. With that in mind, generally speaking, Big Data is:
- large datasets;

- the category of computing strategies and technologies that are used to handle large datasets.

The determination "large dataset" means a dataset too large to reasonably process or store with traditional tooling or on a single computer. It means that the standard scale of Big Data sets constantly shifting and varies significantly from organisation to organisation. Today, there are new challenges 
at designing solutions by Big Data. By the term of new challenges, it means the massive scale, the speed of ingesting and processing, and the characteristics of the data that must be dealt with at each stage of the process. There exist "three Vs of Big Data" to describe some of the characteristics that make big data different from other data processing (Laney, 2001). These are: volume, velocity and variety.

There is far more to consider than this $3 \mathrm{~V}$ such as visualisation, veracity, variability, and value. From the generated data monthly report were created (Fig. 3).

\begin{tabular}{|c|c|c|c|c|c|c|c|c|}
\hline A & 8 & c & D & E & F & G & H & 1 \\
\hline 1 Date & Onigin & Place 10 & Location_ID & Direction & ECIN code $(1,2.6)$ & Nr of oxle & Price cathegory & Wr of vehicles \\
\hline 222017.09 & Kübidi & MESU93K27OM & F478. Otbs 1 & Hitra (monectidnyban csotkkens) & 4 & 2 & $\sqrt{12}$ & 198 \\
\hline 32017.09 & Kulfeldi & MEBU93K270M & F478. Otbs 1 & Hïra (menetitimyban crokkend) & 4 & 3 & 13 & 80 \\
\hline 42017.09 & Konseldi & Mesu93к270M & FA7B-OBOS 1 & Hetra (monetishytan csokkens) & 4 & 4 & 14 & 1169 \\
\hline 5 [ 2017.09 & Kunela & MESU93к270M & F 478 . O1BS 1 & 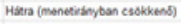 & 5 & 2 & $\Omega$ & 8 \\
\hline 62017.09 & Konseldi & Mesu93k270M & F 478 - ODS 1 & HSera (monetimytoran csokkens) & 5 & 3 & 13 & so \\
\hline 72017.09 & Kunela & MEsu93к270M & F47B. O1BS 1 & Hista (monetrabyban caokkens) & 5 & 4 & $\mu$ & 6272 \\
\hline 8] 2017.09 & Kollesidi & MESU93K270M & F47B - OAbs 1 & 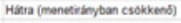 & 6 & 5 & 12 & 65 \\
\hline 92017.09 & Kuneldi & MEsU93к270M & F478. O105 1 & 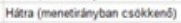 & 6 & 3 & 13 & 61 \\
\hline 10 2017.09 & Kullesdi & MESU93к270M & FA7B - OABS 1 & Hista (menecivinytan csokkens) & 6 & 5 & 54 & 13 \\
\hline III 2017.09 & Mazai & MESU93к270M & FA7B. OBDS 1 & Hivera (monetrimytan csokkens) & 4 & 2 & 12 & 498 \\
\hline 122017.09 & Hazai & Mosu93к270M & FA7B. OBBS 1 & Hista (menecirinytan csokkens) & 4 & 3 & 13 & 105 \\
\hline 132017.09 & Hazai & MESU93катом & FA7B. OABS 1 & Hisra (menetrimytan crokkens) & 4 & 4 & 34 & 425 \\
\hline 142017.09 & Hazai & MеsU93катом & FATB-OBS 1 & Hista (menecivinytan csokkens) & 5 & 2 & $\sqrt{2}$ & 14 \\
\hline$1 5 \longdiv { 2 0 1 7 . 0 9 }$ & Mazai & ME\&U93к270M & FA7B . OABS 1 & Hibra (menetininytan caokkens) & 5 & 3 & 13 & 56 \\
\hline
\end{tabular}

Fig. 3

Example of the Preliminary Report

Source: Own Edition

The monthly data were statistically analysed in order to reveal possible changes as an effect of introduction.

\section{Analysis and Discussion}

The previous analysis of data showed that no significant change in road usage was detectable. The ratio of foreign vehicles to domestic has not significantly fluctuate.

The introduction of dynamic weight-inmotion detection system has not caused significant restructuring of road usage patterns - neither in domestic nor in foreign traffic.

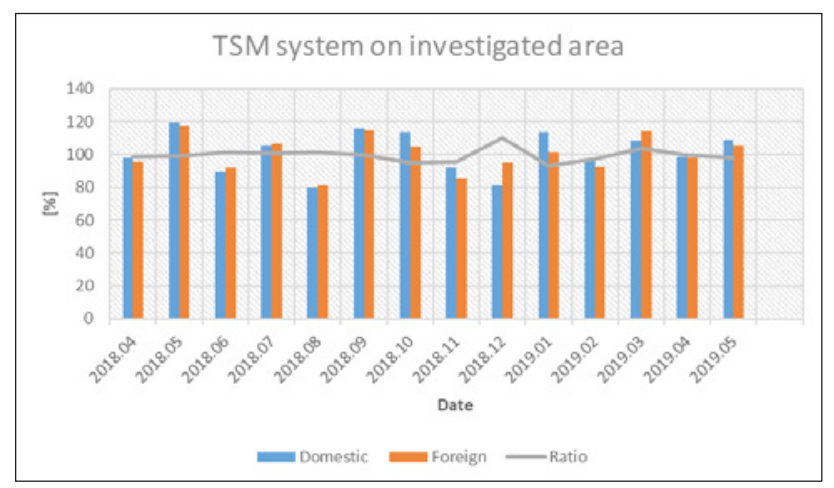

Fig. 4.

Changes in Road Usage Pattern for Vehicle Category J2

Source: Own Edition 
In order to capture changes in traffic, previous months were compared. As it can be seen on Fig. 4, the changes are not significant nor in domestic neither in foreign traffic in category $\mathrm{J} 2$. The average change in $\mathrm{J} 2$ traffic was:
- $\quad 101.6 \%$ in case of domestic traffic with the variance of $12.5 \%$;

- $\quad 100.4 \%$ in case of foreign traffic with the variation of $10.8 \%$;

- the domestic-foreign-ratio average was $99.5 \%$ with $4.2 \%$ variation.

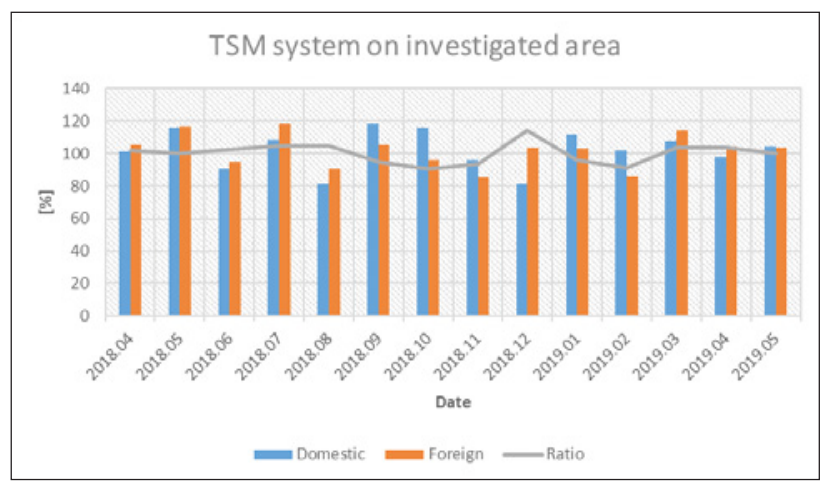

Fig. 5.

Changes in Road Usage Pattern for Vehicle Category J3

Source: Own Edition

In order to capture changes in traffic, the previous months were compared. As can be seen in Fig. 5 the changes are not significant nor in domestic neither in foreign traffic in category J3. The average change in $\mathrm{J} 3$ traffic was:
- $\quad 102.3 \%$ in case of domestic traffic with the variance of $12.0 \%$;

- $\quad 101.9 \%$ in case of foreign traffic with the variation of $10.5 \%$;

- the domestic-foreign-ratio average was $100.1 \%$ with $6.4 \%$ variation.

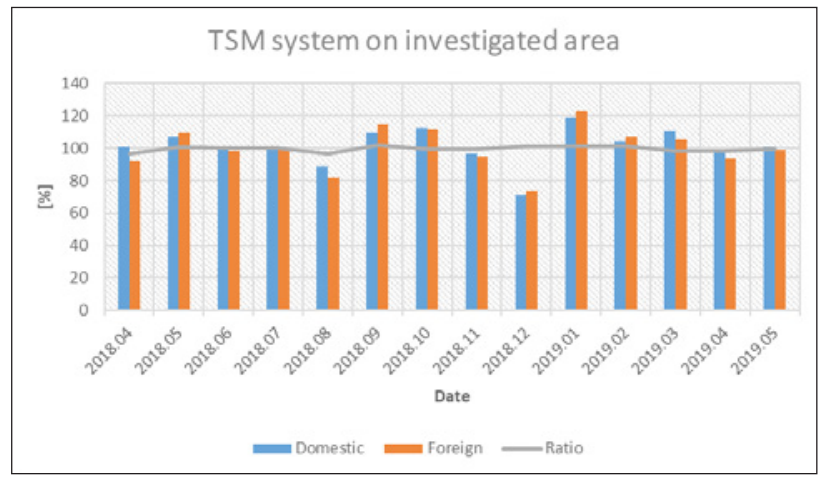

Fig. 6.

Changes in Road Usage Pattern for Vehicle Category J4

Source: Own Edition 
In order to capture changes in traffic, previous months were compared. As can be seen in Fig. 6, the changes are not significant nor in domestic neither in foreign traffic in category J4. The average change in J4 traffic was:

- $\quad 101.3 \%$ in case of domestic traffic with the variance of $11.6 \%$;

- $\quad 100.3 \%$ in case of foreign traffic with a variation of $13.2 \%$;

- the domestic-foreign-ratio average was $99.6 \%$ with $1.7 \%$ variation.
Detailed statistical analysis of preliminary results was conducted separately for domestic and for foreign vehicles. Analysis of time series was done. Based on the results author could conclude that the introduction of the dynamic axle weight measurement system has not caused significant change, but also increased the effectiveness of control.

Fines were applied on 1294 occasions, for the total value of 62.6 million HUF. These fines are five-times more considerable than compared to the five-year average performance of mobile inspection units (Fig. 7).

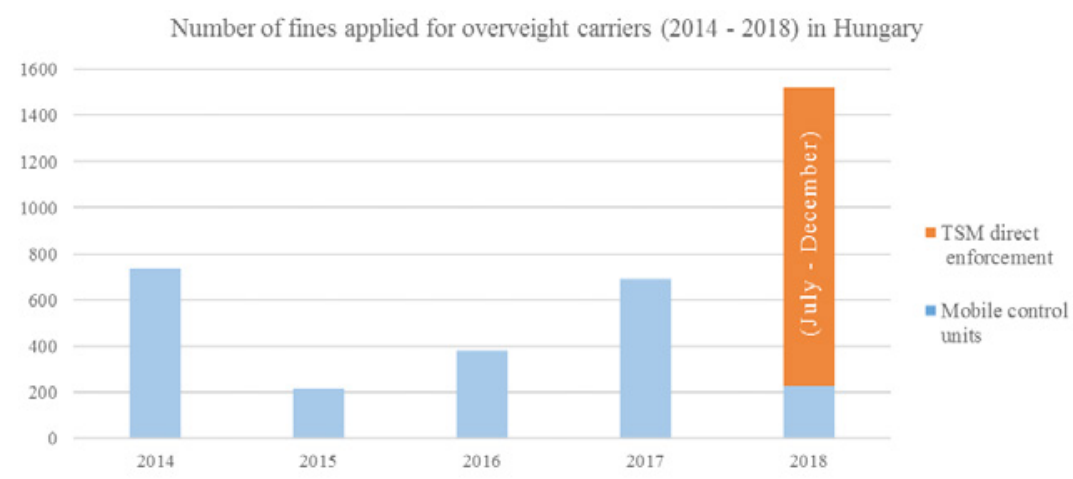

Fig. 7

Annual Number of Fines Imposed on Overweight Trucks

Source: (Ronay-Tobel et al., 2019)

\section{Conclusion}

Apart from the lower acquisition costs provided by the in-bulk purchase of hardware, and several site-specific services such as calibration and maintenance - being conducted in a cost-efficient way, what made the implementation financially feasible was the efficient utilisation of the national road toll system. Vehicle detection, automatic number plate recognition functionality, gantries with power and communication outlets were already granted on the sites. Hence the duplication of roadside infrastructure could be avoided altogether. Another advantage of full network coverage happened to be the potential for selfcorrection, and the immediate detection of sites/sensors with their accuracy suspected being below the required level.

So far, these measures have proved to be an effective method to preserve the public acceptance of Weigh-In-Motion in Hungary. 


\section{References}

Jacob, B.; O’Brien, E.J.; Jehaes, S. 2002. Weigh-inMotion of Road Vehicles - Final Report of the COST323, LCPC, Paris. Available from internet: <https://pdfs. semanticscholar.org/d387/3576868f6cb27a1dc1c66e af0b6120a39090.pdf>.

Laney, D. 2001. 3D data management: Controlling data volume, velocity and variety. META Group Inc., 208 Harbor Drive, P.O. Box 120061, Stamford, CT 06912-0061. 4p. Available from internet: <https:// blogs.gartner.com/doug-laney/files/2012/01/ad949-3DData-Management-Controlling-Data-Volume-Velocityand-Variety.pdf $>$.

Nešić, A.; Čavka, I.; Čokorilo, O. 2015. Shifting to more environmentally friendly modes in long-distance transport. In Proceedings of $2^{\text {nd }}$ international academic conference on places and technologies 2015, Nova Gorica, Slovenia, June 18-19, 479-484.

Oláh, J. 2016. Introduction of operation support technical devices needed for the transportation in the 21st century [in Hungarian: 21. századi fuvarozáshoz szükséges, müködést támogató technikai eszközök bemutatása], Department of Logistics Management, Institute of Applied Informatics and Logistics, Faculty of Economics, University of Debrecen, Hungary, Gradus 3: 454-460.

Oláh, J.; Karmazin, G.; Pető, K.; Popp, J. 2018. Information technology developments of logistics service providers in Hungary, International Journal of Logistics Research and Applications 21(3): 332-344. doi: 10.1080/13675567.2017.1393506.
Oláh, J.; Halasi, G.; Szakály, Z.; Popp, J.; Balogh, P. 2017. The impact of international migration on the labor market-A case study from Hungary, Amfiteatru Economic 19(46): 790-805.

Ronay-Tobel, B.; Mikulas, R.; Katkics, A.; Toldi, M. 2019. Weight Enforcement Network of Hungary (A multilevel case study on WIM). In Proceedings of the $8^{\text {th }}$ International Conference on Weigh-In-Motion - ICWIM8, 19-23 May 2019, Prague, Czech Republic.

Sipos, T. 2014. Coherence between Horizontal and Vertical Curves and the Number of the Accidents, Periodica Polytechnica Transportation Engineering, 42(2): 167-172. doi: 10.3311/PPtr.7403.

Šimecki, A.; Steiner, S.; Čokorilo, O. 2013. The accessibility assessment of regional transport network in the South East Europe, International Journal for Traffic and Transport Engineering 3(4): 351-364. doi: 10.7708/ ijtte.2013.3(4).01.

Török, Á. 2015. Analysing the connection of Hungarian economy and traffic safety, Periodica Polytechnica Transportation Engineering 43(2): 106-110. doi: 10.3311/ PPtr.7953. 